\title{
A Case of Concurrent Non-Intestinal Type Adenocarcinoma and Inverted Papilloma in a Maxillary Sinus
}

\author{
Youn Woo Kim ${ }^{1}$, Jung Woo Shin ${ }^{1}$, Kyu Ho Lee ${ }^{2}$, and Seok-Won Park ${ }^{1} \mathbb{C}$ \\ ${ }^{1}$ Departments of Otorhinolaryngology-Head and Neck Surgery, ${ }^{2}$ Pathology, Dongguk University College of Medicine, Ilsan Hospital, \\ Goyang, Korea
}

\section{비장형 선암종과 반전성 유두종의 상악동에서의 병발 1예}

김윤우 ${ }^{1} \cdot$ 신정우 ${ }^{1} \cdot$ 이규호 $^{2} \cdot$ 박석원 $^{1}$

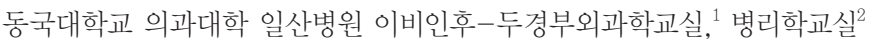

\author{
Received July 6, 2018 \\ Revised August 30, 2018 \\ Accepted September 3, 2018 \\ Address for correspondence \\ Seok-Won Park, MD, PhD \\ Department of Otorhinolaryngology- \\ Head and Neck Surgery, \\ Dongguk University \\ College of Medicine, Ilsan Hospital, \\ 27 Dongguk-ro, Ilsandong-gu, \\ Goyang 10326, Korea \\ Tel +82-31-961-7430 \\ Fax $+82-31-961-7427$
}

E-mailsw43857@dumc.or.kr
Inverted papilloma is a benign epithelial tumor that arises from the sinonasal epithelium and occurs in $0.5-4 \%$ of all sinonasal tumors. Although benign, it is associated with malignant transformation in $2-27 \%$ of the cases, with the most commonly accompanying malignant tumor being squamous cell carcinoma. The malignant transformation of inverted papilloma into adenocarcinoma is extremely rare, with two cases reported worldwide to date. Here, along with a literature review, we report a recent case of a 53-year-old man with non-intestinal type adenocarcinoma associated with a sinonasal inverted papilloma. This case shows the possibility of a malignant transformation of inverted papilloma into non-intestinal type adenocarcinoma, which may be associated with human papilloma virus and thus requires further investigation. Korean J Otorhinolaryngol-Head Neck Surg 2019;62(8):465-9

Key Words Adenocarcinoma · Inverted papilloma · Neoplastic cell transformation · Paranasal sinuses.

\section{서 론}

반전성 유두종은 비강 및 부비동 점막에서 발생하는 양성 상피 종양으로 전체 비강 및 부비동 종양 중 $0.5 \sim 4 \%$ 를 차지 하는 종양이며, 높은 재발률, 국소 침윤, 악성 변화를 특징으 로 하는 질환이다. ${ }^{1,2)}$ 원발부위는 대개 비강의 외측벽이며 흔 히 기시부위에서 이차적으로 상악동 또는 사골동으로 확장 된다. ${ }^{3)}$ 양성 종양이지만 2 27\%에서 악성 변화를 동반할 수 있으며 가장 흔하게 동반하는 악성 종양은 편평세포암이다. ${ }^{3)}$

비부비동 선암종은 비부비동 원발성 악성 종양의 10 20\%

This is an Open Access article distributed under the terms of the Creative Commons Attribution Non-Commercial License (https://creativecommons.org/licenses/by-nc/4.0) which permits unrestricted non-commercial use, distribution, and reproduction in any medium, provided the original work is properly cited.
를 차지하며 타액선형과 비타액선형으로 분류하며, 비타액선 형은 장형(intestinal type) 또는 비장형(non-intestinal type) 으로 분류한다. 비장형은 다시 저악성도와 고악성도로 분류 한다. ${ }^{4)}$

반전성 유두종에서 유래한 악성 종양은 대부분 편평세포 암이며 현재까지 외국 문헌에서 반전성 유두종에 동반하는 선암종의 경우 국내에서는 보고된 바가 없으며 외국 문헌에 서 단 2예만이 보고되고 있다.,6) 그중 1예는 반전성 유두종 에서 유래한 장형 선암종이며 다른 1 예는 반전성 유두종에 동 반하는 선암종으로 보고되며 선암종의 type에 대한 언급은 없었다.

저자들은 최근 상악동에서 반전성 유두종과 병발한 비장형 선암종 1 예를 경험하였기에 문헌 고찰과 함께 보고하는 바이다. 


\section{증 례}

53세 남자 환자가 내원 1 개월 전부터 지속되는 우측 비출혈 을 주소로 내원하였다. 협심증으로 내원 6개월 전부터 아스피 린을 복용하고 있었으며 내원 1개월 전 비출혈이 지속된 이후 로는 아스피린 복용을 중단하고 있었다. 그 외 과거력, 가족 력, 직업력상 특이한 사항은 없었다. 내원 당시 비강 내시경 검
사상 우측 비강을 채우고 있는 불규칙한 표면의 종물이 관찰 되었다(Fig. 1). 부비동 전산화단층촬영상 우측 비강 및 상악 동 내에 비균질 조영증강되는 팽창성 종물이 관찰되었고 우 측 상악동 전벽의 골 미란, 내벽의 부분적 골 파괴 소견이 관 찰되었다(Fig. 2). 또한 우측 개구비도 단위의 폐색으로 인한 이차성 전두동 및 사골동 부비동염 소견이 관찰되었다(Fig. 2). 내시경 및 영상학적 소견을 종합하였을 때 우측 비강 및
Fig. 1. Preoperative endoscopy revealed a mass with an irregular surface in the right nasal cavity. Before decongestant application (A). After decongestant application (B).
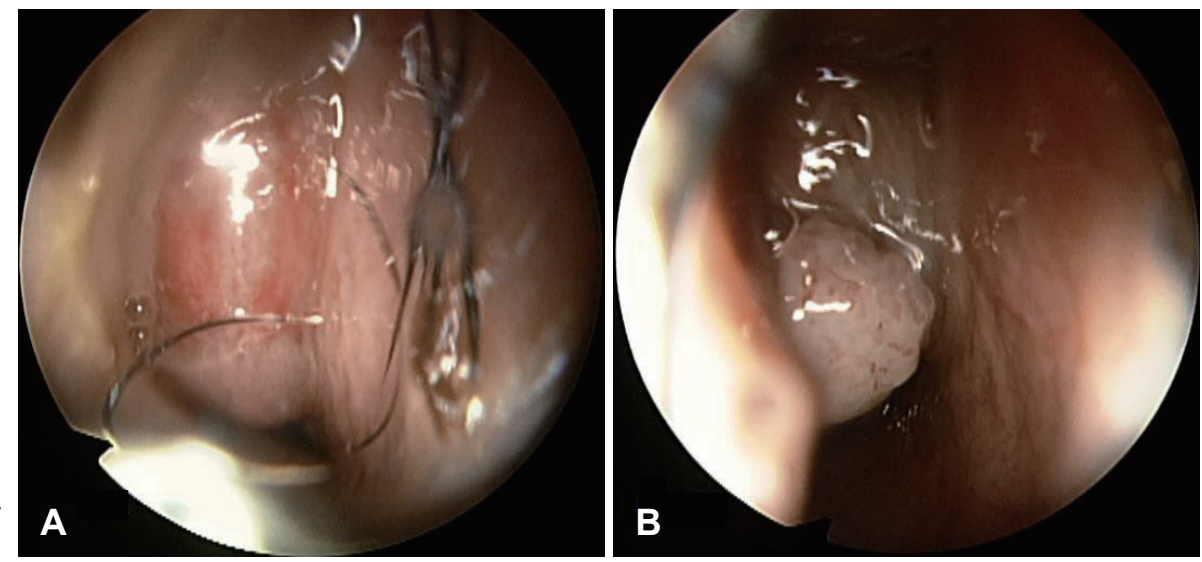

Fig. 2. Preoperative CT scans. Preoperative CT scanning revealed an expansile, heterogenous, contrastenhanced mass in the right nasal cavity and the maxillary sinus. Bone erosion was observed in anterior wall of the right maxillary cavity (A). Bone erosion was observed in inferior wall of right maxillary cavity and partial bone destruction was observed in the medial wall of the right maxillary cavity (B).
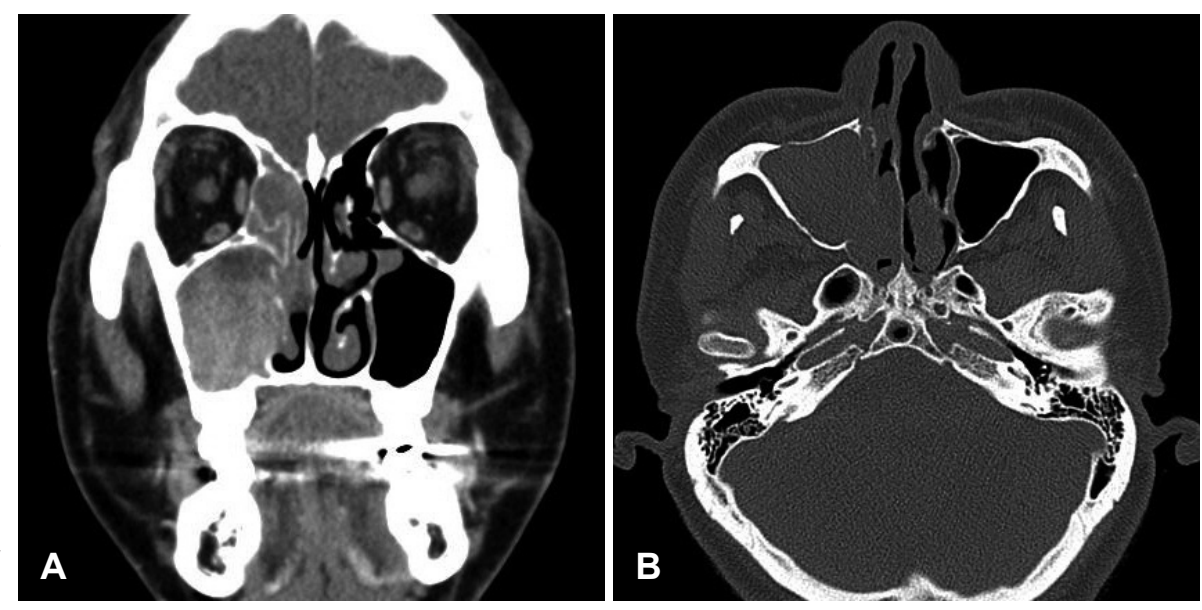
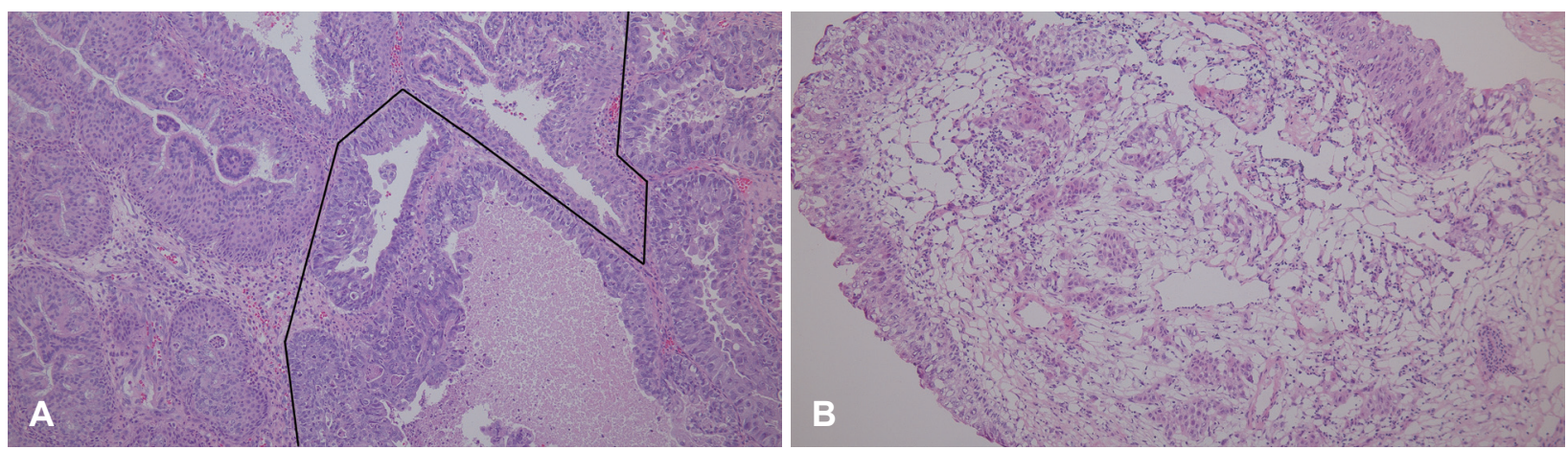

Fig. 3. Histologic findings of coexisting inverted papilloma and carcinoma component. Left upper area shows typical histologic features of inverted papilloma with no cytologic atypia. Right lower area shows histologic features of adenocarcinoma in situ with marked cellular pleomorphism, high mitotic activity, glandular and solid growth pattern $(\mathrm{H} \& \mathrm{E}, \times 100)(\mathrm{A})$. Microinvasion of adenocarcinoma is observed on the frozen section $(\mathrm{H} \& \mathrm{E}, \times 100)(\mathrm{B})$. 
상악동의 반전성 유두종 가능성을 염두에 두고 수술을 계획 하였다.

전신마취하에 비내접근법과 Caldwell-Luc 접근법을 병행 하는 내시경하 상악골 내측 절제술로 종양의 완전 절제를 시 행하였다. 수술 중 기시부를 확인해보려는 시도는 하였으나 명 확히 기시부로 판단되는 소견은 보이지 않았다. 우측 비강 내 종괴 및 상악동 내 병변에 대해서 동결 절편 조직 검사를 시행 하였으며 전자의 경우 반전성 유두종에 합당하다고 보고받 았으며 후자의 경우 일부에서 악성 종양 세포가 확인되었으나 정확한 진단은 불가능하다고 보고받았다. 우측 상악동 병변 에 대해서는 점막을 포함하여 병변을 완전히 제거하였으며 이 후 중비도 상악동개방술(middle meatal antrostomy) 변연부 위에서 동결 절편 조직 검사를 다시 시행하여 종양 세포가 존 재하지 않은 것을 확인 후에 수술을 종료하였다.

병리조직 검사상 우측 비강 및 상악동 병변에 대해서 반전 성 유두종에서 유래한 고악성도 비장형 선암종으로 최종 진단 되었다(Fig. 3). 우측 상악동 병변은 선암종으로 보이는 병리 소견이 다발성(multifocal)으로 혼재하였으며 최대 $0.8 \mathrm{~cm}$ 크 기로 존재하였다. 또한 우측 비강 병변은 약 $1.1 \times 0.7 \times 0.3 \mathrm{~cm}$ 크기로 확인되었다. CK7, CK20, CDX2 특이 단백 항체를 이 용한 면역조직화학검사를 시행하였으며 CK7 양성, CK20 음 성, $\mathrm{CDX} 2$ 음성으로 확인되어 비장형 선암종에 합당하였다 (Fig. 4). 수술 이후 양전자 컴퓨터단층촬영 검사를 시행하였 으며 경부 임파선 전이 및 원격 전이 소견은 관찰되지 않았다.
이상을 종합하였을 때 $\mathrm{T} 2 \mathrm{NOM} 0$ 로 판단하여 최종병기는 Stage II로 진단하였다. 수술 후 방사선 치료는 시행하지 않았 다. 수술 후 6개월째 비내시경 검사상에서 재발 소견은 관찰 되지 않았으며 특별한 합병증 없이 추적 관찰 중이다.

\section{고 찰}

비부비강 내에는 외배엽 기원의 섬모호흡상피로 덮여있으 며 이를 Schneiderian 상피라고 부른다. ${ }^{3)}$ 이들 상피에서 유래 된 유두종은 조직학적 특징에 따라서 반전성(inverted), 버섯 모양(fungiform), 원통형(cylindrical) 유두종으로 분류한다. ${ }^{3)}$ 반전성 유두종은 조직학적으로 종양성 상피가 기질 안으로 내 번하는 양상을 나타내며 병리학적으로는 양성이나 주위 조직 의 침습, 술 후 높은 재발률, 악성 변화 등을 특징으로 한다. ${ }^{2,3)}$

반전성 유두종은 40 70세에서 호발하며 남녀비는 4:1 정 도로 남자에서 보다 호발한다.3,7) 동반하는 증상으로는 편측 성 비폐색 증상이 가장 흔하며 종괴의 개구비도 단위(ostiomeatal unit) 폐색에 따른 이차성 부비동염으로 인한 농성 비루, 후비루 증상이 동반할 수 있다.,7) 본 증례의 환자가 호 소한 반복적인 비출혈은 반전성 유두종 환자 중 $10 \%$ 정도에 서 호소한다. 종양의 기시부위는 비강의 외측벽, 상악동, 사 골종, 접형동 순으로 발생하며 주로 비강의 외측벽에서 발생 한다. ${ }^{3,7)}$

비부비동 비장형 선암종은 소타액선에서 유래하지 않으면
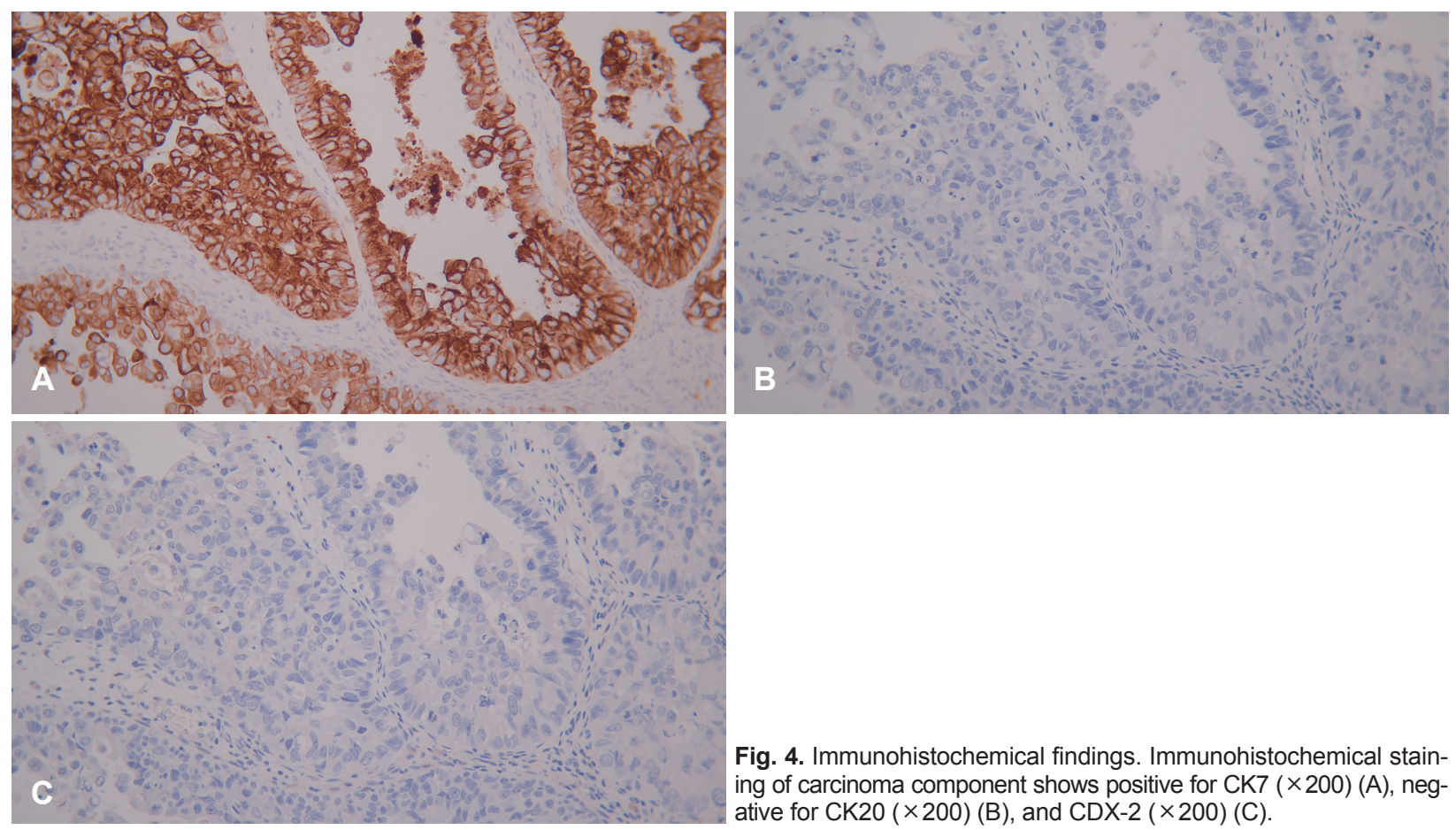

Fig. 4. Immunohistochemical findings. Immunohistochemical staining of carcinoma component shows positive for CK7 $(\times 200)(A)$, negative for CK20 $(\times 200)(B)$, and CDX-2 $(\times 200)(C)$. 
서 병리조직학적으로 장형 선암종의 특징을 나타내지 않는 선암종으로 정의 된다." 비장형 선암종은 다시 조직학적 특징 에 따라 저악성도와 고악성도 분류되며 저악성도 비장형 선 암종은 샘상(glandular) 또는 유두상(papillary)의 성장 양상 을 보이며 고악성도 비장형 선암종은 고형상(solid)의 침습적 성장 양상을 보이고 중등도 이상의 세포 다형성(cellular pleomorphism), 높은 유사분열활성(high mitotic activity)이 관 찰된다. ${ }^{4,8)}$

면역조직화학염색은 종양의 감별에 도움이 되는데, 대장의 선암종은 CK7 음성 및 $\mathrm{CK} 20, \mathrm{CDX} 2$ 양성 반응을 보이며 비 부비동의 장형 선암종은 $\mathrm{CK} 7$ 양성 및 $\mathrm{CK} 20, \mathrm{CDX} 2$ 양성 반 응을 보인다. ${ }^{8)}$ 비장형 선암종은 $\mathrm{CK} 7$ 양성, $\mathrm{CK} 20, \mathrm{CDX} 2$ 음성 반응을 보인다. ${ }^{8)}$ 본 증례에서는 $\mathrm{CK} 7$ 양성 및 $\mathrm{CK} 20, \mathrm{CDX} 2$ 음성이 확인되어 비장형선 선암종임을 확인하였다.

저악성도 비장형 선암종의 경우 예후가 매우 좋으며 고악성 도 비장형 선암종은 3 년 생존율이 $20 \%$ 정도로 예후가 좋지 않다. ${ }^{4}$

비장형 선암종의 치료 원칙은 종양의 완전한 수술적 절제 와 수술 후 방사선 치료이다. 수술 후 방사선 치료에 대한 이 득은 아직까지 명백한 증거는 없으며 종양의 절제면이 양성인 경우 또는 고악성도인 경우에 고려할 수 있다.")

2017년 Kim 등 ${ }^{10)}$ 은 지금까지 보고된 적 없는 반전성 유두 종에서 유래한 비부비동 미분화 암종(sinonasal undifferentiated carcinoma) 1예를 보고하였으며 비부동 미분화암종 치료에 준해서 종양의 완전한 수술적 절제와 수술 후 방사선 치료를 시행하였다. 본 증례에서는 piecemeal 이긴하나 종양 의 완전한 수술적 절제를 시행하였으며 수술 후 방사선 치료는 시행하지 않았다. 2018년 National Comprehensive Cancer Network guideline에 따르면 선양낭포암(adenoid cystic carcinoma)을 제외한 모든 상악동 악성 종양에서 T1-2, N0일 때 수술적 절제를 하고 절제연이 음성인 경우 수술 후 방사선 치 료(adjuvant radiotherapy) 없이 추적 관찰할 수 있다.11)

고전적으로 반전성 유두종의 악성 변화가 각각의 다른 원 발성 암이 동시에 생겨났을 것이라는 이론이 제시된 적도 있 었으나, ${ }^{12)}$ 병리학적으로 양성 반전성 유두종에서 편평상피암 의 악성 변화를 증명하여 고전적 이론을 반박한 보고도 있다. 반전성 유두종의 악성 변화는 2 27\% 정도로 보고되고 있 으며, ${ }^{3)}$ Lawson 등게 에 따르면 2684예 중 240예(8.9\%)에서 편 평상피세포암이 동반되어 있었고 이들 중 130예(67.3\%)에서 동시에 발생(synchronous)하였고 63예(32.6\%)에서 속발성 (metachronous)으로 발생하였다. 동시에 발생하는 병변 (synchronous lesion)은 수술 당시 병리조직학적으로 양성 및 악성 소견이 동시에 관찰되거나 이행대가 관찰되는 경우
이며, 속발성으로 발생하는 병변은(metasynchronous) 수술 적으로 제거 이후 추적 관찰 중 재수술 시행 시 관찰되는 경우 를 말하며 이와 같은 특징으로 인해 반전성 유두종은 오랜 기 간 추적 관찰을 요한다.)

인유두종바이러스(human papilloma virus, HPV)은 반전 성 유두종의 형성(formation), 재발(recurrence), 악성 변화(malignant formation)와 관련이 있는 것으로 알려져 있다. ${ }^{13)}$ Lawson 등ㄹ)은 HPV type을 종양원성(oncogenicity)에 따라 저위 험도와 고위험도로 구분하였고 저위험도의 HPV 6/11 초회 감염은 반전성 유두종 형성과 관련성이 있으며 이후 고위험 도의 HPV $16 / 18$ 감염이 악성 변화를 일으킬 수 있다고 제안하 였다. 이때 악성 변화는 편평이형성(squamous dysplasia) 또 는 편평세포암으로 진행한다고 하였다. ${ }^{13)}$ 본 증례에서 polymerase chain reaction assay를 시행하면 HPV와의 관련성 판 단에 도움이 될 것으로 생각되어 시행하였으나 음성으로 판명 되었다.

인유두종바이러스와 반전성 유두종의 선암종 악성 변화와 의 관련성에 대해서는 연구된 바가 없으나 보다 연구가 활발 히 진행된 자궁경부암에서 선암종과 인유두종바이러스와 관 련성은 잘 알려져 있다. Andersson 등ㄴ)에 의하면 자궁경부 선암(cervical adenocarcinoma) 131예 중 38예(37\%)에서 HPV 18 양성, 31예(24\%)에서 HPV 16 양성임을 확인하였고 HPV 와 자궁경부선암과의 관련성을 증명하였다. 본 증례는 반전성 유두종의 비장형 선암종 악성 변화 가능성을 시사하며 이는 $\mathrm{HPV}$ 와 관련성이 있을 수 있겠으나 본 증례에서는 증명하지 못하였다. 이에 대해서는 향후 추가적인 연구가 필요하겠다.

반전성 유두종에 동반하는 선암종의 경우 국내에서는 보 고된 바가 없으며 외국 문헌에서 단 2예만이 보고되었다. 저자 들은 최근 53세 남자 환자의 상악동에서 발생한 반전성 유두 종과 병발한 비장형 선암종을 경험하였기에 문헌 고찰과 함 께 보고하는 바이다.

\section{ORCID}

Seok-Won Park https://orcid.org/0000-0003-4262-2150

\section{REFERENCES}

1) Lawson W, Kaufman MR, Biller HF. Treatment outcomes in the management of inverted papilloma: an analysis of 160 cases. Laryngoscope 2003;113(9):1548-56.

2) von Buchwald C, Bradley PJ. Risks of malignancy in inverted papilloma of the nose and paranasal sinuses. Curr Opin Otolaryngol Head Neck Surg 2007;15(2):95-8.

3) Barnes L, Tse LL, Hunt JL. Schneiderian papillomas. In: Barnes L, Eveson JW, Reichart P, Sidransky D, editors. Pathology and genetics of head and neck tumours. Vol. 9. 3rd ed. Lyon: IARC Press;2005. p.28-32.

4) Franchi A, Santucci M, Wenig BM. Adenocarcinoma. In: Barnes L, 
Eveson JW, Reichart P, Sidransky D, editors. Pathology and genetics of head and neck tumours. Vol. 9. 3rd ed. Lyon: IARC Press;2005. p. 20-3.

5) Kerschner JE, Futran ND, Chaney V. Inverted papilloma associated with squamous cell carcinoma and adenocarcinoma: case report and review of the literature. Am J Otolaryngol 1996;17(4):257-9.

6) Singh G, Singh M, Chandana M, Singh S, Nargotra N. Intestinal type adenocarcinoma from inverted papilloma: a rare recurrence. J Clin Diagn Res 2016;10(11):ED12-3.

7) Cho JK, Dhong HJ, Chung SK, Kim HY, Jung YG, Min JY. Clinical review of inverted papilloma and oncocytic schneiderian papilloma. Korean J Otorhinolaryngol-Head Neck Surg 2008;51(9):790-5.

8) Leivo I. Sinonasal adenocarcinoma: update on classification, immunophenotype and molecular features. Head Neck Pathol 2016; 10(1):68-74.

9) Lund VJ, Chisholm EJ, Takes RP, Suárez C, Mendenhall WM, Rinaldo A, et al. Evidence for treatment strategies in sinonasal adenocarcinoma. Head Neck 2012;34(8):1168-78.
10) Kim JS, Hong KH, Jang KY, Song JH. Sinonasal undifferentiated carcinoma originating from inverted papilloma: a case report. Medicine (Baltimore) 2017;96(45):e8584.

11) National Comprehensive Cancer Network. Clinical practice guidelines in oncology-head and neck cancers. version 2. 2018. [serial online] 2018 Jun [cited 2018 Jun 20] Available from: URL: https://www. nccn.org/professionals/physician_gls/pdf/head-and-neck.pdf.

12) Ahn HY, Yeo SG, Seok SR, Hong NP, Cho JS, Cha CI, et al. Inverted papilloma and malignant transformation. Korean J OtorhinolaryngolHead Neck Surg 1994;37(2):306-15.

13) Lawson W, Schlecht NF, Brandwein-Gensler M. The role of the human papillomavirus in the pathogenesis of Schneiderian inverted papillomas: an analytic overview of the evidence. Head Neck Pathol 2008;2(2):49-59.

14) Andersson S, Rylander E, Larsson B, Strand A, Silfversvärd C, Wilander E. The role of human papillomavirus in cervical adenocarcinoma carcinogenesis. Eur J Cancer 2001;37(2):246-50. 